\title{
RENCANA PENGELOLAAN TAMAN HUTAN KOTA PENJARINGAN, JAKARTA UTARA
}

\author{
Merrilin Lauren ${ }^{1)}$, Sylvie Wirawati ${ }^{2}$, Liong Ju Tjung ${ }^{3)}$ \\ 1)Program Studi S1 PWK, Fakultas Teknik, Universitas Tarumanagara, merrilinlauren@gmail.com \\ 2) Program Studi S1 PWK, Fakultas Teknik, Universitas Tarumanagara, sylview@ft.untar.ac.id \\ 3) Program Studi S1 PWK, Fakultas Teknik, Universitas Tarumanagara, jt.liong@pps.untar.ac
}

Masuk: 30-07-2021, revisi: 03-09-2021, diterima untuk diterbitkan: 23-10-2021

\begin{abstract}
Abstrak
Pengadaan ruang terbuka hijau menjadi salah satu hal yang penting bagi keseimbangan ekosistem bagi warga perkotaan. Salah satu ruang terbuka hijau di jakarta yang juga memiliki fungsi sebagai ruang resapan air di bagian utara jakarta yaitu Taman Hutan Kota Penjaringan. Namun pemanfaatan Taman Hutan Kota Penjaringan belum optimal dengan masih dapat dijumpai berbagai permasalahan pengelolaan yang ada pada taman tersebut sehingga penelitian ini bertujuan untuk mengetahui kondisi fisik serta potensi dan masalah pada taman dengan menggunakan analisis lokasi, analis daya tarik, analisis sarana dan prasarana, analisis best practices, serta menggunakan sudut pandang pengunjung yaitu persepsi dan preferensi pengunjung terhadap pengelolaan dalam melakukan evaluasi pengelolaan di Taman Hutan Kota Penjaringan. Dari hasil evaluasi yang ada dilakukan penyusunan rencana pengelolaan yang dijadikan usulan rencana pengelolaan bagi pengelola Taman Hutan Kota Penjaringan, Jakarta Utara.
\end{abstract}

Kata kunci: Pengelolaan; Rencana; Taman Hutan Kota.

\begin{abstract}
The procurement of green open space is one of the important things for the balance of the ecosystem for urban residents. One of the green open spaces in Jakarta which also has a function as a water catchment area in the northern part of Jakarta is the Penjaringan City Forest Park. However, the utilization of the Penjaringan City Forest Park has not been optimal with various management problems that exist in the park, so this research was conducted to identify the physical conditions and potentials and problems in the park by using location analysis, attractiveness analysis, facilities and infrastructure analysis, best practices analysis, as well as using the visitor's point of view, namely the perception and preference of visitors to management in evaluating management at the Penjaringan City Forest Park. From the results of the evaluation, $a$ management plan was prepared which was used as a proposed management plan for the manager of the Penjaringan City Forest Park, North Jakarta.
\end{abstract}

Keywords: Management; Planning; Urban Forest Park.

\section{PENDAHULUAN Latar Belakang}

Seiring dengan perkembangan kota, kemajuan transportasi dan sistem utilitas sebagai bagian dari upaya untuk meningkatan kesejahteraan warga kota juga telah menambah pencemaran udara yang menimbulkan berbagai ketidaknyamanan di lingkungan perkotaan seperti polusi udara. Berdasarkan data dari Dinas Lingkungan Hidup, Indeks Standar Pencemaran Udara di wilayah DKI Jakarta menunjukan tren yang terus meningkat sepanjang tahun 2019. Untuk mengatasi kondisi lingkungan kota tersebut diperlukan suatu alat untuk membantu menyeimbangkan ekosistem agar lebih aman dan nyaman bagi warga perkotaan yaitu Ruang Terbuka Hijau (RTH). Pengadaan RTH menjadi sangatlah penting bagi keberlangsungan keseimbangan ekosistem yang lebih nyaman dan aman bagi warga kota. Namun pengadaan RTH juga harus diimbangi dengan pengelolaan RTH yang baik. Hal tersebut menjadi penting untuk dilakukan karena dengan pengelolaan yang baik RTH dapat berfungsi secara optimal bagi kota dan juga masyarakat kota. 
Berdasarkan data dari Dinas Pertamanan dan Pemakaman Pemerintahan Provinsi DKI Jakarta, Jakarta hanya memiliki RTH sebesar 9,98\% dari luas wilayah kota yang terbagi menjadi 3.131 Ruang Terbuka Hijau. Jakarta Utara menjadi wilayah kota administrasi yang memiliki jumlah ruang terbuka hijau paling sedikit di daratan Jakarta dengan jumlah RTH sebanyak 356 RTH. Didasari hal tersebut sangat diperlukan pengembangan RTH di Jakarta khususnya di Jakarta Utara. Dalam memenuhi kebutuhan RTH di Jakarta, Pemerintah melakukan upaya-upaya pengadaan RTH yang salah satu nya terletak di Kecamatan Penjaringan. Kecamatan penjaringan juga merupakan daerah pesisir yang rendah dan dilalui banyak saluran dan aliran air, sehingga penjaringan menjadi kecamatan yang rentan terancam oleh banjir. Serangkaian upaya untuk mengurangi banjir di Kecamatan Penjarinagan telah dilakukan, termasuk dengan dilakukannya relokasi pemukiman, perbaikan drainase, pembangunan tanggul, dan juga pembuatan ruang untuk resapan air. Salah satu ruang yang juga dapat berfungsi sebagai ruang resapan air adalah ruang terbuka hijau Taman Hutan Kota Penjaringan.

Taman Hutan Kota Penjaringan merupakan salah satu upaya pemerintah dalam melakukan pengadaan RTH dengan luas sebesar $135.000 \mathrm{~m}^{2}$ yang dikelola oleh Dinas Pertamanan dan Hutan Kota Provinsi DKI Jakarta. Namun pada Taman Hutan Kota Penjaringan masih dapat dijumpai berbagai permasalahan pengelolaan yang membuat Taman Hutan Kota Penjaringan kurang optimal. Permasalahan-permasalahan tersebut membutuhkan rencana pengelolaan yang baik agar pemanfaatan Taman Hutan Kota Penjaringan dapat optimal. Dengan didasari dari permasalahan pengelolaan yang ada serta dukungan pemerintahan terhadap pengembangan Taman Hutan Kota Penjaringan, hal tersebut menjadi dasar yang mendorong penulis untuk melakukan penelitian lebih lanjut terhadap Taman Hutan Kota Penjaringan khususnya dalam aspek pengelolaan Taman Hutan Kota Penjaringan.

\section{Rumusan Permasalahan}

Pada Taman Hutan Kota Penjaringan masih dapat dijumpai permasalahan terkait dengan pengelolaan dengan adanya penemuan penulis seperti terdapat bangunan liar yang ada disekitar Taman Hutan Kota Penjaringan, tidak terawatnya fisik tapak dengan terdapatnya banyak sampah dan hal lainya, serta banyak pedagang kaki lima yang secara liar berada disekitar Taman Hutan Kota Penjaringan. Hal tersebut mengindikasikan kurang optimalnya pengelolaan Taman Hutan Kota Penjaringan, Jakarta Utara.

\section{Tujuan}

Dalam melakukan penelitian, penulis memiliki tujuan dalam melakukan penelitian yaitu mengetahui kondisi fisik serta aspek-aspek pengelolaan Taman Hutan Kota Penjaringan untuk mengetahui potensi dan masalah yang terdapat pada Taman Hutan Kota Penjaringan, melakukan evaluasi terhadap pengelolaan pada Taman Hutan Kota Penjaringan, memberikan usulan dalam bentuk rencana pengelolaan bagi Taman Hutan Kota Penjaringan.

\section{KAJIAN LITERATUR}

\section{Taman Hutan Kota}

Urban Forest Park (UFP) atau Taman Hutan Kota terletak di dalam kota dan terhubung dengan tempat tinggal warga. Taman hutan kota merupakan sistem ekologis, dan kondisi lingkungannya secara langsung mempengaruhi kualitas hidup dan kesehatan fisik dan mental penduduk. Taman hutan kota yang baik dapat menyerap sebagian $\mathrm{CO} 2$ di kota, melepaskan banyak oksigen, dan menjernihkan udara di kota; Taman hutan kota yang asri, yang bentang alamnya menghadirkan kenikmatan indah bagi masyarakat, menjadi tempat penting untuk olah raga pagi, rekreasi, pariwisata, dan aktivitas warga lainnya. Taman Hutan Kota dikembangkan berdasarkan sumber daya hutan (Chen, Qi, \& Qiu, 2018).Taman hutan adalah taman yang dibangun oleh pemerintah dan badan usaha untuk menyesuaikan dengan kebutuhan rekreasi dan pariwisata warga, 
dengan memanfaatkan kehutanan atau keunggulan lahan yang ada untuk mengembangkan kawasan hutan buatan atau hutan alam yang luas sebagai kawasan wisata (Sanoa, Miyamoto, Furuya, \& Kogi, 2009).

\section{Taman Kota}

Taman kota adalah lahan terbuka yang berfungsi sosial dan estetik sebagai sarana kegiatan rekreatif, edukasi atau kegiatan lain pada tingkat kota. Berdasaran Peraturan Kementrian Pekerjaan Umum No.5 Tahun 2008 tentang Pedoman Ruang terbuka di Kawasan perkotaan, Taman kota melayani minimal 480.000 penduduk dengan luas taman minimal sebesar 144.000 $\mathrm{m} 2$ dan standar luas minimal 0,3 m2 per penduduk kota (Kementrian Pekerjaan Umum, 2008). Taman kota memiliki unsur Comfort, Relaxation, Passive and Active Engagement, dan Discovery (Carr, 1993). Dengan kualitas taman kota yang baik akan dapat memberikan dampak yang positif bagi masyarakat yang menggunakan taman kota tersebut. Berikut merupakan prinsip yang dapat menjadi tolak ukur bagi kualitas taman kota yang baik yaitu aksesibilitas, pengelolaan, aktivitas, permeabilitas dan pergerakan, inklusifitas, kualitas area publik, lingkungan, penerangan, vegetasi dan fleksibelitas, vitalitas, dan keselamatan dan keamanan (Bahriny \& Bell, 2020).Taman kota memiliki standar minimal fasilitas yang harus ada pada sebuah taman kota terdiri dari bangku taman, tempat sampah, lampu taman (penerangan), jalur pedestrian, tempat parkir, plaza (arena serbaguna), toilet, gazebo, papan informasi, instalasi listrik, dan jaringan drainase (Wibowo \& Ritonga, 2016).

\section{Pengelolaan Taman Kota}

Dalam melakukan pengelolaan terhadap taman kota terdapat beberapa aspek pengelolaan yang dapat menjadi indikator dalam mengukur pengelolaan sebuah taman kota. Aspek pengelolaan taman kota tersebut terbagi menjadi 9 yaitu, Keselamatan dan Keamanan, Kebijakan Perencanaan dan Pengelolaan Taman, Fasilitas Taman dan Kualitas Lingkungan, Pengelolaan Tenaga Kerja, Finansial, Fungsi Edukasi, Aksesibilitas dan Informasi, Penggunaan Taman, Keluhan Pengguna tentang Sumber Daya dan Lingkungan Taman (Shing, 2005).

\section{Rencana Pengelolaan Taman Kota}

Menurut Central Park Management Plan 2020-2025 yang dikeluarkan oleh City Services Division and key Central Parks Stakeholders, dalam melakukan penyusunan rencana pengelolaan taman beberapa hal yang perlu menjadi perhatian sebelum membuat Action Plan yaitu kesehatan, keamanan, dan keselamatan, kebersigan dan pemeliharaan yang baik, pengelolaan lingkungan, konservasi dan heritage, keterlibatan komunitas, pemasaran, dan manajemen (City Services Division and key Central Parks Stakeholders, 2019).

\section{Aspek Pengelolaan Taman Kota}

Dalam penelitian ini aspek pengelolaan yang digunakan merupakan gabungan aspek dari teori dan Central Park Management Plan 2020-2025 oleh City Services Division and key Central Parks Stakeholders di Southampton, Inggris yaitu Kebijakan Perencanaan dan Pengelolaan Taman, Penggunaan Taman, Aksesibilitas dan Informasi, Pemeliharaan dan Pengelolaan Fasilitas Taman dan Lingkungan, Konservasi dan Heritage, Keterlibatan Komunitas, Keselamatan dan Keamanan, Kebersihan dan Pengelolaan Sampah, Pemasaran dan Manajemen.

\section{Rekreasi}

Menurut Panov dalam Basic Of Tourism, kebutuhan rekreasi wisatawan dapat didefinisikan sebagai salah satu motivasi utama berwisata. Hal tersebut didefinisikan dari pengertian pariwisata yaitu merupakan sekumpulan hubungan dan fenomena yang berkaitan dengan pergerakan dan konsumsi di luar tempat tempat tinggal, dalam rangka memenuhi kebutuhan rekreasi dan budaya (Panov, 2006). 


\section{METODE}

Metode pengumpulan data dilakukan dengan observasi lapangan, wawancara, kuisioner, dan pengumpulan dokumen. Identifikasi kondisi fisik serta aspek pengelolaan dilakukan menggunakan analisis lokasi, analisis sarana dan prasarana, dan analisis daya tarik. Evaluasi aspek pengelolaan menggunakan analisis best practices, analisis karakteristik pengunjung, dan analisis persepsi dan preferensi pengunjung. Analisis daya tarik menggunakan metode analisis SWOT untuk mengidentifikasi potensi dan masalah pada objek studi. Analisis karakteristik pengunjung dan analisis persepsi preferensi dilakukan menggunakan metode IPA (Importance Performance Analysis) dengan pengumpulan data menggunakan kuisioner dengan jumlah responden sebesar 120 orang. Usulan rencana pengelolaan dilakukan dengan analisis rencana pengelolaan dengan menggunakan aspek pengelolan yang telah ditentukan.

\section{DISKUSI DAN HASIL}

\section{Analisis Sarana dan Prasarana}

Pada Taman Hutan Kota Penjaringan dapat dilihat bahwa masih terdapat beberapa sarana dan juga prasarana yang masih membutuhkan peningkatan baik dari sisi pengelolaan dan juga pemenuhan kebutuhan sarana dan prasarana pada Taman Hutan Kota Penjaringan. Kebutuhan sarana dan prasarana yang dibutuhkan di Taman Hutan Kota Penjaringan merupakan pos keamanan, bangku taman, fasilitas bermain anak, sentra PKI, air bersih, lampu taman, dan tempat pengelolaan sampah pada Taman Hutan Kota Penjaringan. Dari analisis diatas, dapat di ketahui juga bahwa terdapat beberapa permasalahan pengelolaan sarana dan prasarana yang ada di Taman Hutan Kota Penjaringan yaitu dengan adanya parkir liar disepanjang gerbang masuk yang mengganggu aksesibilitas, batas taman yang tidak terawat sehingga dijadikan akses utama keluar masuk pemukiman disekeliling taman yang membuat taman terlihat tidak bersih karena banyak tumpukan barang milik warga pemukiman sekitar, terdapat banyak pedagang kaki lima yang berjualan disekitar taman yang tidak tetata dengan baik, dan tidak ada sistem pengelolaan sampah taman yang baik sebab semua sampah dibuang pada bagian belakang taman dan di bakar sehingga mengganggu kenyamanan pada taman.

\section{Analisis Daya Tarik}

Taman Hutan Kota Penjaringan memiliki potensi untuk melakukan pengembangan khususnya taman yang berdekatan dengan Taman Hutan Kota Penjaringan yaitu RPTRA Kalijodo dengan adanya kolaborasi. RPTRA Kalijodo dan Taman Hutan Kota Penjaringan hanya berjarak 251 meter. Dengan keterdekantan antara kedua taman tersebut dapat mejadi peluang bagi masingmasing taman untuk dapat meningkatkan interaksi sosial pada masing-masing taman. Dengan keunikan dan ciri khas Taman Hutan Kota Penjaringan, dapat menjadi salah satu daya tarik bagi pengujung khususnya bagi warga ibukota atau warga yang tinggal di kawasan residensial sekitar yang saat ini sudah jarang atau sulit menemukan area terbuka hijau yang luas sehingga Taman Hutan Kota Penjaringan memiliki potensi untuk dilakukan pengembangan pengelolaan lebih lagi. Namun aksesibilitas, sedikitnya variasi kegiatan yang disebabkan oleh sedikitnya instrumen penunjang kegiatan, serta pedagang kaki lima yang tidak tertata menjadi permasalahan yang perlu diselesaikan oleh pengelola.

\section{Analisis Best Practices}

Analisis best practices dilakukan berguna untuk melihat sistem pengelolaan terkait taman kota yang serupa dengan objek penelitian. Informasi mengenai pengelolaan taman kota masingmasing objek diuraikan dengam menggunakan 9 aspek pengelolaan yang digunakan didalam penelitian. Objek taman kota yang digunakan adalah Central Park yang terletak di Kota Southampton, Inggris dan Taman Hutan Kota Keputih yang terletak di Kota Surabaya, Indonesia. Pada analisis ini dapat disimpulkan bahwa pengembangan Taman Hutan Kota Penjaringan masih 
dapat dilakukan dengan mengadaptasi metode-metode pengelolaan yang diterapkan oleh kedua objek pembanding baik khususnya pada aspek penggunaan taman, aksesibilitas dan informasi, pemeliharaan fasilitas taman dan lingkungan, kebersihan dan pengelolaan sampah, serta manajemen dan pemasaran. Pembenahan struktur baik dari struktur organisasi, alur pelaporan, dan alur pengelolaan sampahyang dilakukan objek pembanding sangat baik sehingga dapat diadaptasi untuk pengelolaan Taman Hutan Kota Penjaringan, Jakarta Utara.

\section{Analisis Karakteristik Pengunjung}

Taman Hutan Kota Penjaringan. Karakteristik pengunjung didominasi oleh pengunjung yang jenis kelamin laki-laki $(62,50 \%)$, berusia 56-65 Tahun (20.83\%), berdomisili di Jakarta Utara $(54,17 \%)$, pekerjaan pengunjung yang mendominasi merupakan wiraswasta $(34,17 \%)$, pendapatan perbulan $\mathrm{Rp} 5.000 .001-\mathrm{Rp} 10.000 .000$ (40,83\%), pengunjung berkunjung di hari libur (sabtu, minggu, atau tanggal merah) sebesar $62,50 \%$, dengan waktu kunjungan yang mendominasi yaitu pada sore hari $(14.00$ - 18.00) sebesar 59,17\%, dengan tujuan kunjungan yang mendominasi untuk kegiatan olahraga $(54,17 \%)$, rekan kunjungan pengunjung yang dominan adalah dsatang sendiri yait sebesar $35 \%$, pengunjung dominan dating menggunakan sepeda motor pribadi $(60,83 \%)$, serta daya tarik yang membuat pengunjung ingin berkunjung karena taman memiliki banyak pohon yang membuat terasa sejuk $(53,33 \%)$.

\section{Analisis Persepsi dan Preferensi Pengunjung}

Dalam Analisis Persepsi dan Preferensi Pengunjung, metode yang digunakan merupakan metode IPA (Importance Performance Analysis) untuk mengukur hubungan antara persepsi pengunjung dengan prioritas peningkatan kualitas pelayanan dengan diagram kartesius yang terbagi menjadi 4 kuadran yang meliputi kuadran I (Prioritas Utama), Kuadran II (Pertahankan Prestasi), Kuadran III (Prioritas Rendah), Kuadran IV (Berlebihan). Pemetaan kuadran Importance Performance Analysis dapat dilihat pada diagram kartesius berikut:

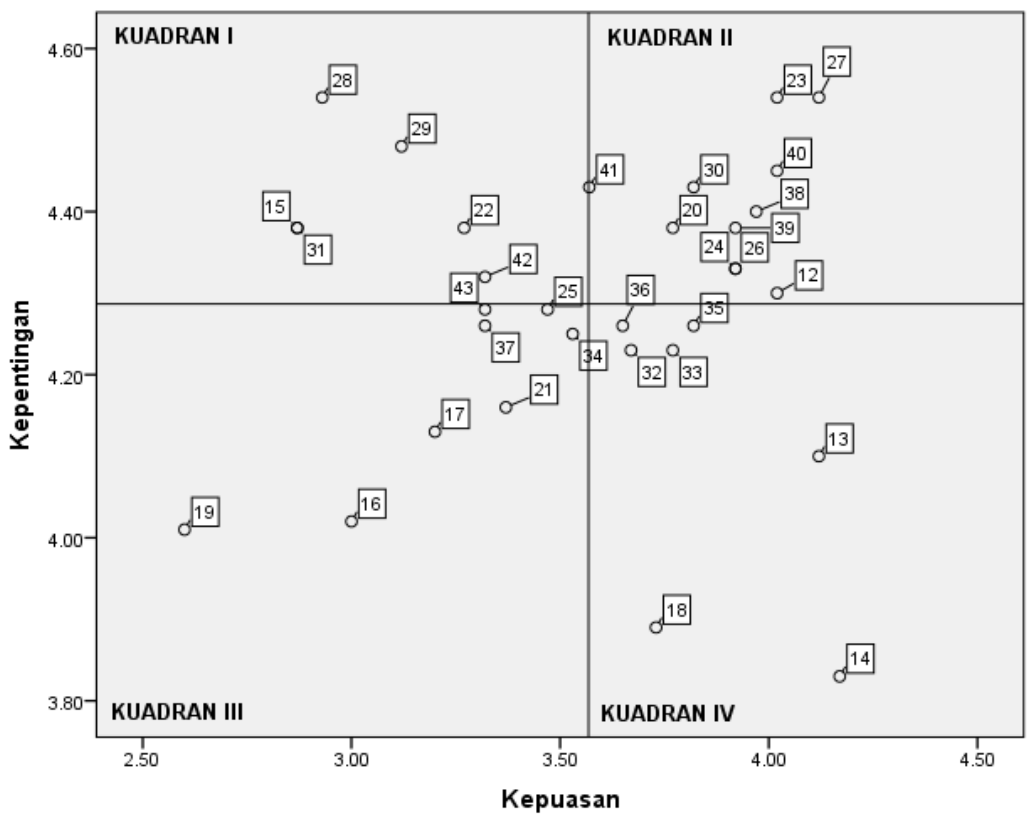

Gambar 1. Diagram Kartesius Prioritas Pengelolaan

Berdasarkan analisis IPA, indikator-indikator dalam aspek pengelolaan yang perlu menjadi prioritas utama merupakan kualitas air bersih, kondisi kebersihan taman, variasi aktivitas yang dapat dilakukan dalam taman, pengelolaan sampah, ketersediaan dan kondisi gazebo, pemasaran terkait keberadaan taman, dan banyaknya event yang dilakukan didalam taman. 


\section{Analisis Rencana pengelolaan}

Dalam melakukan perencanaan pengelolaan pada Taman Hutan Kota Penjaringan, terdapat 9 aspek pengelolaan yang akan dibahas yaitu Kebijakan Perencanaan dan Pengelolaan Taman, Penggunaan Taman, Aksesibilitas dan Informasi, Pemeliharaan Fasilitas Taman dan Lingkungan, Kebersihan dan Pengelolaan Sampah, Konservasi dan Heritage, Keterlibatan Komunitas, Keselamatan dan Keamanan, Menejemen \& Pemasaran.

\section{Kebijakan Perencanaan dan Pengelolaan Taman}

Menurut Rencana Detail Tata Ruang 2030, Taman Hutan Kota Penjaringan memiliki kode 01.057.H.4.b, 01.058.H.4.b, dan 01.059.H.4.b. Kode yang tedapat didalam Rencana Detail Tata Ruang 2030 menyatakan bahwa Taman Hutan Kota Penjaringan masuk ke dalam Zona Ruang Terbuka Hijau dengan Sub Zona Jalur Hijau (H.4). Dalam Rencana Pola Ruang Kecamatan Penjaringan yang tertulis didalam Rencana Detail Tata Ruang 2030 bahwa Zona Jalur Hijau yang berada di Kelurahan Penjagalan Blok 01 direncanakan untuk adanya pengembangan jalur baru dan pemeliharaan jalur hijau. Kebijakan terkait dengan Taman Hutan Kota Penjaringan pada Rencana Detail Tata Ruang 2030 seharusnya dapat dibuat sejalan serta mendukung upaya pemerintah dalam pengembangan Taman Hutan Kota Penjaringan sebagai Taman Hutan Kota yang memiliki peruntukan sebagai tempat rekreasi dan olahraga beserta fasilitasnya didominasi areal hijau/lansekap untuk fungsi ekologis dan juga area resapan. Keterdekatan antara Taman Hutan Kota Penjaringan dan RPTRA Kalijodo yang memiliki satu jalur penghubung sepanjang 255 meter dapat dijadikan sebuah jalur penghubung yang meningkatkan interaksi pada taman. Jalur tersebut terletak pada Jalan Kepanduan 2. Dengan dibuatnya sebuah ruang penghubung antara Taman Hutan Kota Penjaringan dan RPTRA Kalijodo dapat meningkatkan interaksi pada taman. Ruang-ruang penghubung yang dapat dibuat pada jalur tersebut dapat berupa jalur pedestrian yang dihiasi dengan hiasan mural karena pada jalan kepanduan 2 merupakan jalan lokal yang berada disamping Kali Banjir Kanal.

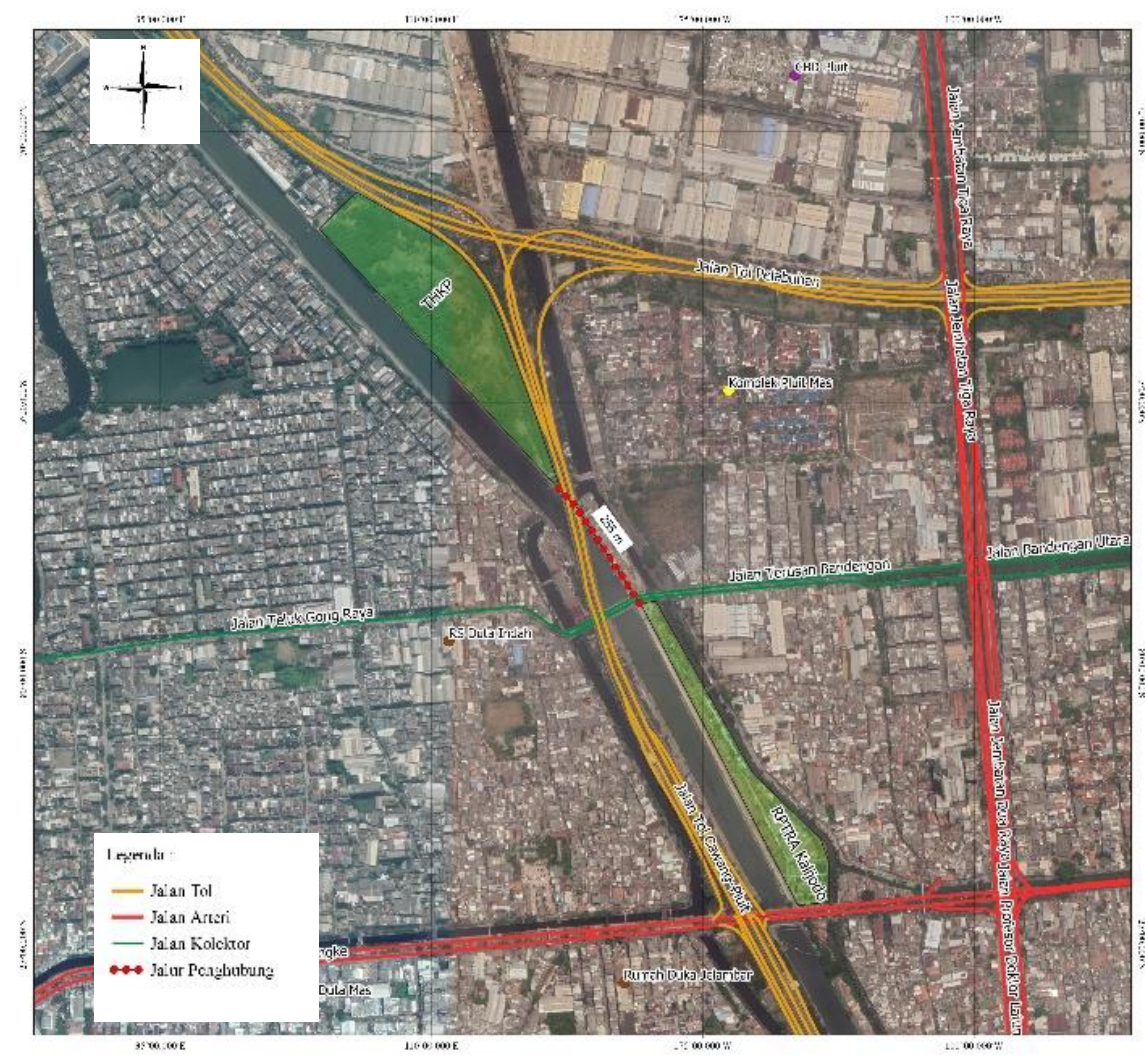

Gambar 2. Jalur Penghubung Antara Taman Hutan Kota Penjaringan dan RPTRA Kalijodo 


\section{Penggunaan Taman}

Taman Hutan Kota Penjaringan memiliki potensi dalam melakukan pengembangan taman khususnya variasi penggunaan taman yang merupakan aktifitas atau kegiatan yang dapat dilakukan pada taman. Dengan konsep hutan kota tersebut banyak variasi kegiatan penggunaan taman yang bisa dilakukan di Taman Hutan Kota Penjaringan, seperti dengan adanya penggunaan untuk berolahraga, bersantai, rekreasi, dan kegiatan edukasi. Dengan adanya pengembangan dalam penggunaan taman Taman Hutan Kota Penjaringan dapat lebih bervariasi dan dapat meningkatkan interaksi pengunjung didalam Taman. Penambahan fasilitas penting diadakan untuk menunjang aktivitas dan interaksi pengunjung dalam menggunakan Taman Hutan Kota Penjaringan. Dalam menunjang variasi aktivitas pengunjung yang ada serta untuk memenuhi kebutuhan yang dibutuhkan oleh pengunjung, Taman Hutan Kota Penjaringan perlu menambahkan fasilitas yaitu bangku taman, fasilitas bermain anak, fasilitas peribadahan, sentra PKL, lapangan olahraga, dan ruang loker.

\section{Aksesibilitas dan Informasi}

Dalam memperbaiki aksesibilitas, perlu melakukan perbaikan terhadap pembatas taman yaitu pagar Taman Hutan Kota Penjaringan agar aksesibilitas pada taman tidak terganggu dengan adanya kegiatan akses keluar dan masuk pemukiman sekitar taman. Selain itu, akses didalam taman juga perlu dilakukan pengelolaan dengan penambahan jalur sepeda sehingga tidak membahayakan pengunjung yang berkunjung, sebab dengan menggunakan jalur yang sama, hal tersebut dapat meningkatkan resiko kecelakaan yang terjadi pada taman. Serta dalam menunjang ketersediaan informasi dan juga kegiatan edukasi, pengelola dapat menambahkan papan informasi terkait informasi vegetasi sebagai sarana edukasi dan menggunakan sosial menida sebagai sarana informasi-infrormasi terkait jadwal, kegiatan, serta informasi lainnya mengenai Taman Hutan Kota Penjaringan.

\section{Pemeliharaan Fasilitas dan Lingkungan}

Pemeliharaan fasilitas dilakukan dengan sistem pemantauan yang rutin dengan pelaksanaan inspeksi untuk memastikan kondisi fasilitas dan lingkungan taman terawat dan dapat berfungsi dengan baik, serta melakukan pencatatan terhadap hasil inspeksi yang dilaporkan kepada pengelola secara berkala untuk dapat dilakukan tindak lanjut dari hasil inspeksi yang dilakukan. Pemeliharaan fasilitas dan lingkungan yang menjadi prioritas saat ini adalah pengadaan prasarana air bersih atau PDAM pada lingkungan Taman Hutan Kota Penjaringan.

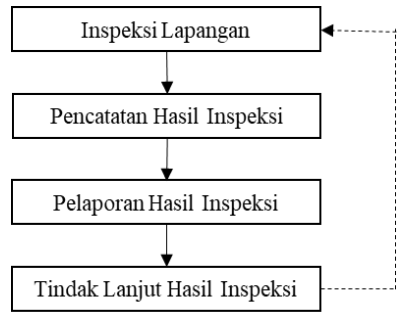

Gambar 3. Alur Pengawasan Pemeliharaan Fasilitas dan Lingkungan

\section{Kebersihan dan Pengelolaan Sampah}

Dalam melakukan perencanaan dalam kebersihan dan pengelolaan sampah, pengelola perlu menyediakan tempat pemilahan sampah dan melakukan pemilahan sampah baik sampah organik dan juga non-organik. Setelah melakukan pemilahan, sampah-sampah tersebut dapat diolah dan digunakan (seperti kompos atau produk daur ulang) atau dilakukan pengumpulan untuk ditransportasikan ke Tempat Pembuangan Akhir. 


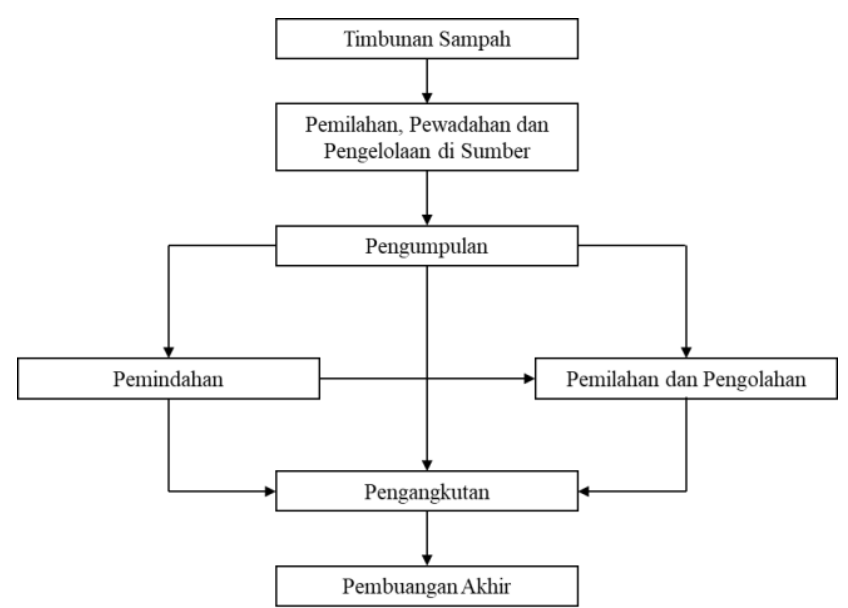

Gambar 4. Diagram Teknik Operasional Pengelolaan Persampahan

Sumber: SNI 19-2454-2002 Tentang tata Cara Teknik Operasional Pengelolaan Sampah Perkotaan,2002

\section{Konservasi dan Heritage}

Konservasi khusunya bagi vegetasi di Taman Hutan Kota Penjaringan dapat dilakukan dengan melakukan penanaman serta penaburan bibit-bibit bunga tanaman hias yang dapat menambah keindahan di Taman Hutan Kota Penjaringan. Keberadaan taman bunga di Taman Hutan Kota Penjaringan dapat menjadi nilai tambah bagi pengembangan Taman Hutan Kota Penjaringan sehingga variasi vegetasi di Taman Hutan Kota Penjaringan tidak hanya terbatasi dengan keberadaan pepohonan tapi juga ada bunga-bunga yang menarik seperti bunga sepatu, bunga matahari, dan bunga lainnya. Untuk konservasi fauna, pada Taman Hutan Kota Penjaringan dapat memasang kotak sarang untuk burung liar dapat hinggap yang diletakan di atas pohon pada Taman Hutan Kota Penjaringan, Hal ini berguna untuk menambah keanekaragaman hayati yang terdapat di Taman Hutan Kota Penjaringan, Jakarta Utara.

\section{Keterlibatan Komunitas}

Keterlibatan komunitas menjadi salah satu hal penting dalam pengelolaan sebab dengan adanya keterlibatan komunitas, pengelolaan dan pengembanan taman dapat sejalan dan menjawab kebutuhan serta harapan dari komunitas dan juga pengunjung yang menggunakan Taman Hutan Kota Penjaringan. Dengan menyediakan ruang komunikasi antara komunitas serta pengunjung dengan pengelola Taman Hutan Kota Penjaringan, pengembangan pengelolaan Taman dapat sesuai dengan aspirasi komunitas dan juga menghidupkan interaksi sosial pada Taman Hutan Kota Penjaringan. Ruang komunikasi dapat berupa ruang diskusi atau acara yang membangun keakraban antar pengelola dan komunitas sehingga hubungan pengelola dan komunitas dapat terjalin dengan baik serta komunitas memiliki rasa memiliki terhadap Taman Hutan Kota Penjaringan dalam menggunakan serta merawat taman.

\section{Keselamatan dan Keamanan}

Dalam rangka menjaga keamanan dan keselamatan pengunjung selama berada di lingkungan Taman Hutan Kota Penjaringan, perawatan dan peninjauan secara rutin terhadap fasilitas yang terdapat di Taman Hutan Kota Penjaringan. Peninjauan dilakukan melibatkan penilaian terhadap kondisi baik secara fisik dan juga fungsi agar seluruh fasilitas yang berada di Taman Hutan Kota Penjaringan aman untuk digunakan oleh pengunjung Taman Hutan Kota Penjaringan. Hasil dari penilaian fasilitas yang dilakukan secara rutin perlu dilaporkan kepada pengelola yaitu Dinas Pertamanan dan Hutan Kota Provinsi DKI Jakarta sehingga pengelola dapat dengan segera menanggapi hasil penilaian fasilitas yang telah dilakukan. Peningkatan keamanan juga perlu dilakukan khususnya pada area dalam Taman Hutan Kota Penjaringan melalui kegiatan patroli yang dilakukan oleh petugas keamanan dan penambahan titik pos penjaga keamanan sehingga 
penjagaan tidak hanya dilakuakn pada area depan taman namun tersebar hingga pada bagian belakang Taman Hutan Kota Penjaringan.

\section{Manajemen \& Pemasaran}

Peningkatan pemasaran dapat dilakukan dengan penggunaan sosial media sebagai sarana pemasaran dan memeperkenalkan Taman Hutan Kota Penjaringan kepada masyarakat melalui platform sosial media yang sering digunakan seperti Instagram. Namun, pemasaran tidak hanya terbatas dengan penggunaan sosial media saja, tapi dapat pemasaran untuk mengenalkan Taman Hutan Kota Penjaringan dapat juga dilakukan dengan membuat event atau kegiatan yang dilaksanakan di Taman Hutan Kota Penjaringan seperti kegiatan peringatan Hari Pohon Sedunia, kegiatan olahraga, atau festival lokal yang diadakan di Taman Hutan Kota Penjaringan.

Dalam melakukan manajemen terdapat 2 aspek yang perlu menjadi perhatian pengelola yaitu manajemen sumber daya manusia dan manajemen finansial. Dalam melakukan manajemen sumber daya manusia, diperlukan struktur organisasi yang ringkas dan jelas serta fungsi yang jelas disetiap jabatan dalam susunan organisasi yang ada. Berikut meruakan usulan struktur organisasi pengelolaan Taman Hutan Kota Penjaringan, Jakarta Utara

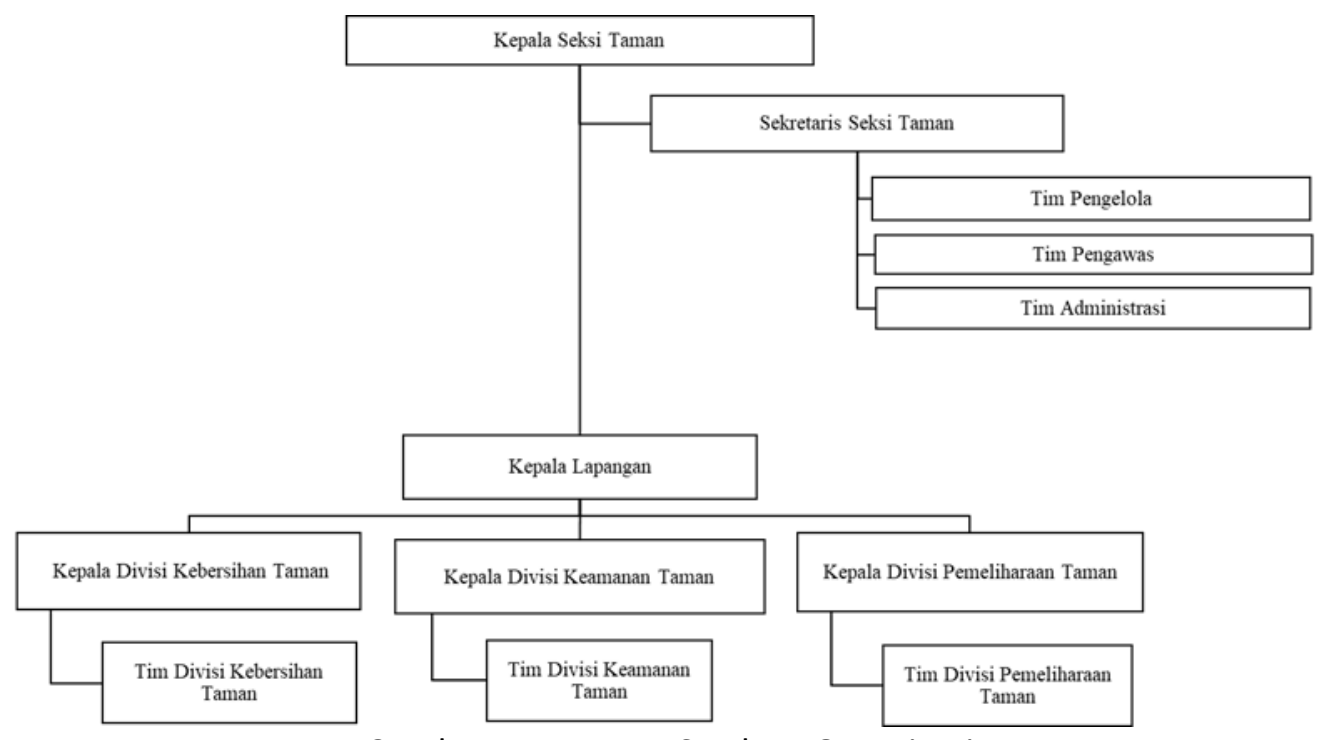

Gambar 5. Rencana Struktur Organisasi

Selain manajemen sumber daya manusia, aspek finansial menjadi salah satu aspek yang juga perlu menjadi perhatian pengelola. Dalam melakukan pengelolaan sangat diperlukan rencana anggaran pengelolaan rutin yang dikeluarkan setiap tahun untuk melakukan pemeliharaan, perawatan, serta operasional setiap bulannya. Pembiayaan pemeliharaan dan operasional dilakukan menggunakan pembiayaan dari pemeritahan daerah dengan sumber dana yaitu APBD (Anggaran Pendapatan dan Belanja Daerah) DKI Jakarta. Tahun anggaran APBD meliputi masa 1 tahun yang dimulai dari tanggal 1 Januari sampai dengan tanggal 31 Desember, sedangkan untuk biaya pengadaan fasilitas dapat menggunakan skema Public Private Partnership atau Kerjasama Pemerintah dan Badan Usaha (KPBU) yang merupakan Kerjasama antara badan usaha dan pemerintahan untuk menyediakan infrastruktur kepentingan umum yang mengacu kepada spesifikasi yang sebelumnya telah ditetapkan oleh Menteri/Kepala Lembaga/Kepala Daerah/BUMN/BUMD yang sebagian atau seluruhnya menggunakan sumber daya Badan Usaha dengan memerhatikan pembagian risiko diantara para pihak yang terkait.

Usulan rencana pengelolaan yang telah dibuat oleh penulis didasari oleh evaluasi yang dilakukan dalam analisis dan persepsi dan preferensi pengunjung serta observasi lapangan dan wawancara yang dilakukan penulis dengan pengelola yaitu Dinas Pertamanan dan Hutan Kota DKI Jakarta, petugas pengamanan, petugas kebersihan, dan warga lingkungan sekitar Taman Hutan Kota 
Penjaringan. Berdasarkan usulan rencana pengelolaan yang telah dibuat oleh penulis dan rencana revitalisasi fisik Taman Hutan Kota Penjaringan yang telah dibuat oleh pihak pengelola, memiliki beberapa perbedaan khususnya dalam penambahan fasilitas. Seluruh rencana revitalisasi fisik yang telah dibuat terdapat didalam rencana pengelolaan yang diusulkan penulis namun dalam rencana pengelolaan yang diusulkan penulis memiliki beberapa penambahan fasilitas khususnya dalam pembangunan ruang/jalur penghubung antara RPTRA Kalijodo dan Taman Hutan Kota Penjaringan, pembangunan sentra PKL, penambahan ruang loker, pembangunan lapangan olahraga, penambahan papan informasi pada vegetasi, Pengadaan pagar pembatas taman, instalasi air bersih (PDAM), dan penanaman bunga-bunga hias. Dengan adanya rencana pengelolaan yang dibuat oleh penulis, diharapkan dapat menjadi usulan untuk rencana pengelolaan Taman Hutan Kota Penjaringan serta menjadi usulan atau masukan untuk rencana revitalisasi fisik Taman Hutan Kota Penjaringan dalam memenuhi kebutuhan setiap orang yang menggunakan atau berkunjung di Taman Hutan Kota Penjaringan.

\section{KESIMPULAN DAN SARAN Kesimpulan}

Taman Hutan Kota penjaringan hanya memiliki 1 akses masuk yaitu melalui Jalan Kepanduan 2 yang merupakan sebuah jalan lokal dipinggir Kali Banjir Kanal serta layanan transportasi umum yang tersedia menuju Jalan Kepanduan 2 tidak bervariasi atau hanya dapat diakses oleh angkot, sehingga aksesibilitas menuju Taman Hutan Kota Penjaringan cukup sulit untuk dijangkau. Pada Taman Hutan Kota Penjaringan masih terdapat beberapa sarana dan juga prasarana yang masih membutuhkan peningkatan baik dari sisi pengelolaan dan juga pemenuhan kebutuhan sarana dan prasarana pada Taman Hutan Kota Penjaringan. Kebutuhan sarana dan prasarana yang dibutuhkan di Taman Hutan Kota Penjaringan merupakan pos keamanan, bangku taman, fasilitas bermain anak, sentra PKL, air bersih, lampu taman, dan tempat pengelolaan sampah pada Taman Hutan Kota Penjaringan. Fasilitas-fasilitas tersebut dibutuhkan karena tidak dimiliki oleh Taman Hutan Kota Penjaringan. Permasalahan pengelolaan sarana dan prasarana juga terdapat di Taman Hutan Kota Penjaringan yaitu dengan adanya parkir liar disepanjang gerbang masuk Taman Hutan Kota Penjaringan yang mengganggu aksesibilitas, batas taman yang tidak terawat sehingga dijadikan akses utama keluar masuk pemukiman disekeliling taman yang membuat taman terlihat tidak bersih karena banyak tumpukan barang milik warga pemukiman sekitar, terdapat banyak pedagang kaki lima yang berjualan disekitar taman yang tidak tetata dengan baik, dan tidak ada sistem pengelolaan sampah taman yang baik sebab semua sampah dibuang pada bagian belakang taman dan di bakar sehingga mengganggu kenyamanan pada taman.

Taman Hutan Kota Penjaringan memiliki banyak potensi pengembangan jika dilakukan pengelolaan yang baik. Konsep hutan kota yang jarang dimiliki taman kota lainnya menjadi salah satu kekuatan utama Taman Hutan Kota Penjaringan serta luas taman yang sangat besar memungkinkan pengelola untuk dapat melakukan pengembangan yang lebih baik untuk meningkatkan interaksi sosial pada Taman Hutan Kota Penjaringan. Letak yang strategis berada di wilayah residensial juga memungkinkan Taman Hutan Kota Penjaringan untuk menjadi ruang interaksi sosial bagi warga lokal sekitar serta dengan keterdekatan Taman Hutan Kota Penjaringan dengan RPTRA Kalijodo dapat menjadi salah satu peluang untuk dapat saling berkolaborasi meningkatkan interaksi sosial sesuai dengan fungsi masing-masing taman.

Berdasarkan evaluasi pengelolaan melalui analisa persepsi dan preferensi pengunjung, indikator aspek pengelolaan yang perlu menjadi prioritas utama dalam pengelolaan adalah kualitas air bersih, kondisi kebesihan taman, variasi aktivitas yang dapat dilakukan dalam taman, pengelolaan sampah, ketersediaan dan kondisi gazebo, pemasaran terkait keberadaan taman, banyaknya event yang dilakukan didalam taman perlu menjadi prioritas utama pengelola untuk 
melakukan peningkatan pengelolaan atau pengembangan pengelolaan. Berdasarkan usulan pengunjung, penambahan bangku taman, fasilitas bermain anak, sarana peribadahan, dan sentra PKL juga merupakan usulan-usulan prioritas yang dianggap penting oleh pengunjung untuk dilakukan penambahan pada Taman Hutan Kota Penjaringan.

Dengan adanya identifikasi kondisi fisik baik sarana dan prasarana, aksesibilitas, potensi dan masalah serta daya tarik di Taman Hutan Kota Penjaringan serta evaluasi yang dilakukan yang melibatkan persepsi dan preferensi pengunjung serta objek pembanding untuk mengevaluasi pengelolaan di Taman Hutan Kota Penjaringan diharapkan pengelolaan Taman Hutan Kota Penjaringan dapat dilakukan peningkatan dan pengembangan agar memiliki pengelolaan yang lebih baik dan sesuai dengan kebutuhan serta dapat memaksimalkan potensi Taman Hutan Kota Penjaringan sebagai taman kota.

\section{Saran}

Dalam rangka meningkatkan pengelolaan, pengelola Taman Hutan Kota Penjaringan perlu memperhatikan 9 aspek pengelolaan Taman Hutan Kota Penjaringan yaitu Kebijakan Perencanaan dan Pengelolaan Taman, Penggunaan Taman, Aksesibilitas dan Informasi, Pemeliharaan Fasilitas Taman dan Lingkungan, Kebersihan dan Pengelolaan Sampah, Konservasi dan Heritage, Keterlibatan Komunitas, Keselamatan dan Keamanan, Manajemen \& Pemasaran. Peningkatan pengelolaan perlu dilakukan oleh pengelola dengan menyusun rencana pengelolaan pada setiap aspek pengelolaan sebagai berikut.

\section{Kebijakan Perencanaan dan Pengelolaan}

Menghubungkan Taman Hutan Kota Penjaringan dengan RPTRA Kalijodo dengan membuat sebuah ruang penghubung antara Taman Hutan Kota Penjaringan dan RPTRA Kalijodo untuk dapat meningkatkan interaksi sosial pada taman-taman tersebut. Ruang-ruang penghubung yang dapat dibuat pada jalur tersebut dapat berupa jalur pedestrian yang dihiasi dengan hiasan mural yang menghubungkan kedua taman.

\section{Penggunaan Taman}

Dalam pengembangan pengunaan taman, Taman Hutan Kota Penjaringan berpotensi untuk digunakan sebagai tempat berolahraga, rekreasi, bersantai, dan edukasi. Dalam memenuhi penggunaan taman tersebut perlu dilakukan penambahan fasilitas untuk memaksimalkan pengunaan taman yaitu penambahan bangku taman, fasilitas bermain anak, musholla, sentra PKL, lapangan olahraga, dan ruang loker.

\section{Aksesibilitas dan Informasi}

Melakukan perbaikan terhadap pembatas taman (pagar taman) Selain itu, melakkan penambahan jalur sepeda untuk mengurangi resiko kecelakaan dan unsur keselamatan pengunjung pada taman. Serta dalam menunjang ketersediaan informasi dan juga kegiatan edukasi, pengelola dapat menambahkan papan informasi terkait informasi vegetasi sebagai sarana edukasi dan menggunakan sosial menida sebagai sarana informasi-infrormasi terkait jadwal, kegiatan, serta informasi lainnya.

\section{Pemeliharaan Fasilitas dan Lingkungan}

Pemeliharaan fasilitas dilakukan dengan sistem pemantauan yang rutin dengan pelaksanaan inspeksi, serta melakukan pencatatan yang dilaporkan kepada pengelola secara berkala untuk dapat dilakukan tindak lanjut segera. Pemeliharaan fasilitas dan lingkungan yang menjadi prioritas adalah pengadaan prasarana air bersih atau PDAM. 
5. Kebersihan dan Pengelolaan Sampah

Menyediakan tempat pemilahan sampah dan melakukan pemilahan sampah baik sampah organik dan juga non-organik. Setelah melakukan pemilahan, sampah-sampah tersebut dapat diolah dan digunakan (seperti kompos) atau dilakukan pengumpulan untuk ditransportasikan ke Tempat Pembuangan Akhir.

\section{Konservasi dan Heritage}

Melakukan penanaman serta penaburan bibit-bibit bunga tanaman hias. Selain itu, melakukan penambahan sarang burung berupa kotak yang dipasang pada pohon sebagai rumah untuk burung-burung liar yang hinggap di taman.

\section{Keterlibatan Komunitas}

Menyediakan ruang komunikasi antara komunitas serta pengunjung dengan pengelola Taman Hutan Kota Penjaringan. Ruang komunikasi dapat berupa pertemuan untuk pengadaan gathering dan lainnya.

\section{Keselamatan dan Keamanan}

Melakukan penilaian terhadap kondisi baik secara fisik dan juga fungsi terhadap seluruh fasilitas. Hasil dari penilaian fasilitas yang dilakukan secara rutin perlu dilaporkan kepada pengelola sehingga dapat segera menanggapi hasil penilaian fasilitas yang telah dilakukan. Peningkatan keamanan juga perlu dilakukan melalui kegiatan patroli yang dilakukan oleh petugas keamanan dan penambahan titik pos penjaga keamanan.

\section{Manajemen dan Pemasaran}

Melakukan pemasaran dengan meningkatkan penggunaan sosial atau dapat membuat event/kegiatan yang dilaksanakan di Taman Hutan Kota Penjaringan seperti kegiatan peringatan Hari Pohon Sedunia, kegiatan olahraga, atau festival lokal. Dalam melakukan manajemen sumber daya manusia, pengelola dapat membentuk struktur organisasi baru, sedangkan dalam manajemen finansial, pengelola dapat meggunakan skema Public Private Partnership dalam melakukan pendanaan terhadap rencana pengadaan fasilitas yang ingin dilakukan.

Dengan demikian, rencana pengelolaan yang ada dapat menjadi usulan atau masakukan dalam melakukan pengelolaan di Taman Hutan Kota Penjaringan bagi pengelola Taman Hutan Kota Penjaringan yaitu Dinas Pertamanan dan Hutan Kota Pemerintah Provinsi DKI Jakarta dalam melakukan pengelolaan di Taman Hutan Kota Penjaringan, Jakarta Utara.

\section{REFERENS}

Badan Standarisasi Nasional. (2002). Sumber: SNI 19-2454-2002 Tentang tata Cara Teknik Operasional Pengelolaan Sampah Perkotaan.

Bahriny, F., \& Bell, S. (2020). Patterns of Urban Park Use and Their Relationship to Factor of Quality: A Case Study of Tehran, Iran. Sustainability.

Carr, S. (1993). Public Space Environtment and Behavior Binding. Cambridge University Press Date Published.

Chen, B., Qi, X., \& Qiu, Z. (2018). Recreational Use of Urban Forest Parks: a case Study in Fuzou National Forest Park, China. Journal of Forest Research, 23(4), 183-189. doi:10.1080/13416979.2018.1432304

City Services Division and key Central Parks Stakeholders. (2019). Central Parks Management Plan 2020 - 2025. Southampton.

Kementrian Pekerjaan Umum. (2008). Peraturan Kementrian Pekerjaan Umum No.5 Tahun 2008 tentang Pedoman Ruang terbuka di Kawasan perkotaan.

Panov, N. (2006). Basics of Tourism. Skopje: FOIK. 
Sanoa, M., Miyamoto, A., Furuya, N., \& Kogi, K. (2009). Using Landscape Metrics and Topographic Analysis to Examine Forest Management in a Mixed Forest, Hokkaido, Japan. Guidelines for Management Interventions and Assessment of Cover Changes, 257(4), 1208-1218.

Shing, C. C. (2005). Development of Indicators for a Sustainable Urban Park Management: Hong Kong: The Chinese University of Hong Kong.

Wibowo, A., \& Ritonga, M. (2016, November). Kebutuhan Pengembangan Standar Nasional Indonesia Fasilitas Taman Kota. Jurnal Standarisasi, 18, 161-170. 
